\title{
Production and Quality Evaluation of Cookies from Wheat, Almond Seed and Carrot Flour Blends
}

\author{
Mulak Desmond Guyih ${ }^{1, ~ *, ~ A h u r e ~ D i n n a h ~}{ }^{2}$, Mike Ojotu Eke $^{2}$ \\ ${ }^{1}$ Department of Chemistry, Faculty of Science, Benue State University/Center for Food Technology and Research, Makurdi, Nigeria \\ ${ }^{2}$ Department of Food Technology, Faculty of science, Federal University of Agriculture Benue, Makurdi, Nigeria
}

Email address:

mulakdesmond@gmail.com (M. D. Guyih)

${ }^{*}$ Corresponding author

\section{To cite this article:}

Mulak Desmond Guyih, Ahure Dinnah, Mike Ojotu Eke. Production and Quality Evaluation of Cookies from Wheat, Almond Seed and Carrot Flour Blends. International Journal of Food Science and Biotechnology. Vol. 5, No. 4, 2020, pp. 45-51. doi: $10.11648 /$ j.ijfsb.20200504.11

Received: March 9, 2020; Accepted: April 14, 2020; Published: October 30, 2020

\begin{abstract}
Cookies are a form of baked food which is usually sweet. Wheat, almond and carrot flours were used to produce cookies in the following blend ratios: 100:0:0, 90:10:0, 90:0:10, 80:15:5, 70:20:10 and were labeled A, B, C, D and E. The control sample A was without treatment. Analyses of antinutrients, functional properties, physical, proximate, minerals, and sensory attributes were carried out using standard methods. All the results show statistical difference. The functional properties of flours: bulk density, WAC, OAC, swelling capacity and foaming capacity ranged respectively from 0.71 to $0.81 \mathrm{~g} / \mathrm{cm}^{3}, 1.60$ to $4.31 \mathrm{~g} / \mathrm{mL}, 1.10$ to $3.67 \mathrm{~g} / \mathrm{L}, 2.30$ to $2.66 \mathrm{~mL}, 5.10$ to $6.62 \%$. The antinutritional properties: oxalate, tannin and cyanide content of flours ranged from 0.03 to $0.14 \mathrm{mg} / 100 \mathrm{~g}, 0.18$ to $0.64 \%, 0.12$ to $0.13 \%$, phytate content was not detected. The spread ratio of cookies ranged from 3.32 in sample A to 4.04 in sample E. The proximate composition of cookies: moisture, ash, fiber, fat, protein and carbohydrate content ranged respectively: from 6.42 to $8.04 \%, 1.62$ to $2.72 \%, 0.36$ to $0.97 \%, 1.94$ to $6.02 \%, 6.14$ to $10.23 \%$ and 71.27 to $81.18 \%$. The energy value of cookies ranged from 371.22 to $391 \mathrm{kCal}$. The mineral composition ranged from 185.77 to $230.16 \mathrm{mg} / 100 \mathrm{~g}$ for calcium, 877.62 to $984 \mathrm{mg} / 100 \mathrm{~g}$ for potassium, 5.75 to $7.12 \mathrm{mg} / 100 \mathrm{~g}$ for zinc, $58.96 \mathrm{mg} / 100 \mathrm{~g}$ to $77.16 \mathrm{mg} / 100 \mathrm{~g}$ for magnesium and 47.03 to 56.12 for sodium. All cookies samples were generally accepted by sensory panelist. The study provides evidence that wheat, almond and carrot are suitable for cookies production and at optimal substitution levels of 70:20:10 and 80:20:10.
\end{abstract}

Keywords: Cookies, Fortification, Nutrients, Antinutrients

\section{Introduction}

Cookies are chemically leavened product which is baked in an oven for usually a short period of time, there are also known as "biscuit". Cookies are ideal for nutrients availability, inexpensiveness, palatability, compactness and convenience, but they differ from other baked products like bread, cakes because of their low moisture content, cookies are comparatively free from microbial spoilage and have a long shelf life. They are ready to eat, convenient and inexpensive or less expensive food products, containing digestive and dietary principles of vital importance [1]. They are nutritive snacks produced from unpalatable dough's which are transformed into appetizing product through the application of heat in the oven [1]. In making cookies, the principle ingredients are wheat flour, sugar, fat, baking and water. These are mixed together with other ingredients (baking powder, skimmed milk, emulsifier and sodium metabisulphite) to form dough containing a well gluten developed network.

Wheat (Triticum aestivum L.) is one of the most important cereal crops for the majority of world's populations (It is the most important staple food of about two $36 \%$ of the world population). Worldwide nutritional statistics shows that, wheat provides nearly $55 \%$ carbohydrates and $20 \%$ food calories consumed globally; it is the most important cereal crop of the world, which is cultivated over a wide range of climatic and environmental conditions [2]. Almonds (Prunus amygdalus) is one of the popular tree nuts in western diets. 
Almonds are a nutrient dense source with respect to its macronutrient content; protein (16-27g of kernel weight), carbohydrates, lipids ( $>50 \%$ of kernel weight), dietary fiber (10.8- 13.5 of kernel weight) and its minerals content (iron, calcium, potassium, magnesium, phosphorous, zinc manganese, selenium and especially high in potassium $(750 \mathrm{mg} / 100 \mathrm{~g})$ and phosphorus $(484 \mathrm{mg} / 100 \mathrm{~g})$. Of this nutrients, lipids and vitamins $\mathrm{E}$ feature in the health profile of almonds relating to the high lipophilic anti-oxidation property [3]. Raw carrots (Daucus carota $L$ ) are used as fresh for salads, cooked as vegetable dish, and easily converted into juice drink. Carrot is a rich source of beta carotene (precursor of vitamin A), B complex vitamins and minerals including calcium, copper, magnesium, potassium, phosphorus, iron and folic acid. It is estimated that carrot juice yield is about $60-70 \%$, while almost $80 \%$ of carotene is lost with surplus carrot pomace [4]. Left over carrot pomace powder contains good residual amount of vitamins, minerals and dietary fiber. So far it does not find proper utilization. Moisture content in carrot reaches up to $80 \%$ that shows its highly perishable nature [5]. Carrots used for baking should therefore be oven dried than used from pomace in other to contain more nutrients.

There has been the call for a strategic development to use less expensive local raw crops in the production of staple foods been promoted by organizations like WHO, FAO and the United Nations refugee feeding programs [6]. This led to the initiation of the composite flour programs, the objective of which is to seek ways of substituting flours, starches, minerals and protein concentrates from indigenous crops, for as much wheat as possible in baked products [6]. Compositing cookies with almond seeds and carrot flour blend are expected to substantially improve the energy efficiency. Moreover, formulation of foods from low-lysine staples such as grains (wheat) fortified with vegetables, legumes and seeds have been proposed as a practical and sustainable approach to improving the protein, mineral nutritional value of foods for vulnerable people in developing countries. This is applicable especially in famine and war situations where there is the need to provide a one stop whole meal with all the required nutritional components that will cater for the nutritional needs of both the young and elderly victims. The simplicity and ease of production makes cookies the best choice as excellent carriers of blends of different and varied functional ingredients, without obvious detraction from the sensory quality and shelf stability of the resultant products. Thus cookies can be formulated into food products that contain all the nutrients needed by the body [7].

\section{Material and Methods}

\subsection{Procurement of Raw Materials}

Carrots, wheat, almond seeds, margarine, sugar, eggs, baking powder and were purchased from the modern market Makurdi, Benue State of Nigeria. Procured materials were then taken to the Chemistry department, Benue State
University laboratory for processing.

\subsection{Preparation of Flour}

Almond seeds were sorted/clean and washed, oven dried at $60^{\circ} \mathrm{C}$ for 2 hours and then ground into flour using laboratory grinders (M/S Sujata: New Delhi India). The almond flour was sieved using a $0.5 \mathrm{~mm}$ size mesh. Carrots was sorted, cleaned, washed and cut into smaller sizes of $1 \mathrm{~cm}$ cubes and then blanched by immersion at $70^{\circ} \mathrm{C}$ for 5 minutes. The carrot cubes were dried at $50^{\circ} \mathrm{C}$ for 24 hours and then milled into flour. The carrot flour produced was sieved through a 0.5 mm size mesh.

\subsection{Preparation of Composite Flour Blends}

Composite flours were prepared from wheat flour almond seeds flour and carrot flour at different levels of substitution as in Table 1. Cookies were prepared from the fortified flours with a little modification of the method described by Okoye et al., [8] as is indicated in Table 2.

Table 1. Composition of flour blends.

\begin{tabular}{ll}
\hline Samples & Wheat: almond: carrot flour ratio \\
\hline A & $100: 0: 0$ \\
B & $90: 10: 0$ \\
C & $90: 0: 10$ \\
D & $85: 15: 5$ \\
E & $70: 20: 10$ \\
\hline
\end{tabular}

Table 2. Recipe for the formulation of cookies from wheat flour, almond seed and carrot flour blends.

\begin{tabular}{ll}
\hline Component & Cookies composition $(\mathrm{g})$ \\
\hline Flour $(\mathrm{g})$ & 100 \\
Margarine $(\mathrm{g})$ & 45 \\
Sugar $(\mathrm{g})$ & 45 \\
Egg $(\mathrm{mL})$ & $30 \mathrm{ml}$ \\
Baking powder $(\mathrm{g})$ & 2 \\
\hline
\end{tabular}

\subsection{Method}

The creaming method was used for the preparation of dough where fat (margarine) and sugar were creamed together using a Kenwood mixer at medium speed for two (2) min. After creaming, ingredients such as flour (flour blend), baking powder and egg were added and mixed to form dough and properly mixed (details on table 2). The dough was manually kneaded to ensure uniformity. The dough was transferred to a clean tray and gently rolled using a roller where the dough was then cut into round shapes using a cutter. Shaped dough pieces were placed into a greased pan and baked in an oven at $180^{\circ} \mathrm{C}$ for $40 \mathrm{~min}$. The baked cookies were removed from the oven and placed on a cooling rack for $30 \mathrm{~min}$ to cool before packaging them [8].

\subsection{Physical, Chemical and Mineral Analysis}

Functional properties of flours from wheat, almond seed and carrot were determined as follows: The water absorption capacity was determined using the method described by Onwuka [9]. Ten milliliters $(10 \mathrm{~mL})$ of distilled water was 
added to $1 \mathrm{~g}$ of the flour sample in a weighed centrifuge tube. The tube was agitated on a vortex mixer for 2 minutes and then centrifuged at $4000 \mathrm{rpm}$ for 20 minutes. The clear supernatant was decanted and discarded. The adhering drops of water were removed and then weighed. Water absorption capacity was expressed as the weight of water bound by 100 $\mathrm{g}$ of dried flour.

$$
\text { WAC }\left(\frac{\mathrm{ml}}{\mathrm{g}}\right)=\frac{\text { water absorped }(\mathrm{ml})}{\text { weight of sample }(\mathrm{g})}
$$

[Water absorbed $(\mathrm{ml})=($ Volume of water added $20 \mathrm{~mL}$ Volume of water obtained after centrifugation)].

The oil absorption capacity was determined using the method described by Onwuka [9]. One gram (1 g) of the flour sample was mixed with $10 \mathrm{~mL}$ of refined vegetable oil and allowed to stand at ambient temperature for $30 \mathrm{~min}$. It was then centrifuged for $30 \mathrm{~min}$ at $2000 \mathrm{rpm}$. The oil and adhering drops of oil was decanted and discarded. Oil absorption capacity was expressed as percent oil bound per gram of flour.

$$
O A C=\frac{W 1-W 2}{W 3} X 100
$$

Where;

$\mathrm{W} 1=$ Weight of sample after centrifugation, W2=Weight before centrifugation, W3=Weight of original sample.

The bulk density of the flour was determined using the method described by Onwuka [9]. The flour sample (5 g) was poured into a $(10 \mathrm{~mL})$ dry measuring cylinder and the volume was recorded for the loose bulk density. The bottom of the cylinder was tapped 80 times on the laboratory table and the volume was recorded for packed bulk density.

$$
\text { Bulk density }\left({ }^{g} / \mathrm{cm}^{3}\right)=\frac{\text { weight of sample }}{\text { volume of sample after tapping }}
$$

The foaming capacity and stability was determined using the method described by Onwuka [9]. Two grams ( $2 \mathrm{~g})$ of the composite flour sample was added to $50 \mathrm{~mL}$ of distilled water at $30 \pm 2^{\circ} \mathrm{C}$ in a $100 \mathrm{ml}$ graduated cylinder. The suspension was mixed and shaken manually for $5 \mathrm{~min}$ to foam. The volume of foam at 0 second after whipping was expressed as foaming capacity using the formula;

$$
\text { Foaming capacity }=\frac{\text { volume of foam after wipping }}{\text { volume of mixture }} X 100
$$

The volume of foam is recorded at different time intervals (5, 10, 15 and 20 seconds) after whipping to determine the foam stability as percent of the initial foam volume.

The swelling capacity was determined using the method described by [10]. One gram ( $1 \mathrm{~g})$ of flour sample was mixed with $10 \mathrm{~mL}$ of water in a weighed centrifuge tube. The tube was then heated in water bath at $85^{\circ} \mathrm{C}$ for $15 \mathrm{~min}$ and then centrifuged at $2000 \mathrm{rpm}$ for $30 \mathrm{~min}$. The clear supernatant was decanted and discarded. The adhering drops of water was removed and then weighed. Swelling capacity was expressed as percent swelled per gram flour.

The dried samples were analyzed for the presence of antinutrients using different method as follows: for hydrogen cyanide determination, $5 \mathrm{~g}$ of the sample was soaked in distilled water for 4 hours for the liberation of cyanide. The liberated cyanide was then steam-distilled into $5 \mathrm{~mL}$ of $2.5 \%$ w/v $4 \mathrm{~mL}$ of $6 \mathrm{~N} \mathrm{NH}_{4} \mathrm{OH}$ and $5 \% \mathrm{w} / \mathrm{v}$ KI was added to the distillate portion before titration with $0.02 \mathrm{~N} \mathrm{AgNO3}$ to a faint but permanent turbidity ( $\mathrm{ml}$ of $0.02 \mathrm{~N} \mathrm{AgNO} 3=1.08 \mathrm{mg}$ $\mathrm{HCN}$ ). Oxalate was determined using the Dye method [11]. $2.5 \mathrm{~g}$ of the sample was extracted with dilute $\mathrm{HCl}, 5 \mathrm{ml}$ of concentrated ammonia and precipitated with $\mathrm{CaCl}_{2}$ as calcium oxalate. The precipitate was washed with $20 \mathrm{~mL}$ of $25 \% \mathrm{H}_{2} \mathrm{SO}_{4}$ and dissolved in hot water before titrating with $0.05 \mathrm{~N} \mathrm{KMnO}_{4}$ to determine the concentration of oxalate. Tannins were determined using Burn method [11]. $5 \mathrm{~g}$ of the dried sample was treated with $50 \mathrm{~mL}$ methanol and kept for 24 hours before filtration. $5 \mathrm{~mL}$ of freshly prepared vanalin hydrochloric acid was added and the solution was allowed to stand for $20 \mathrm{~min}$ for color development. The absorbance was measured at $550 \mathrm{~nm}$ using spectronic 20 and the machine value was used in calculating the tannin content.

Proximate and mineral composition of cookies where analysed using standard method described by AOAC [12].

\subsection{Sensory Evaluation}

Sensory evaluation of cookies was carried out using 30 panelist comprising $\mathrm{MSc} / \mathrm{PhD}$ students of the Food Science and Technology course of the chemistry department, Benue State University Makurdi. Cookies were made with same quantity as commercially sold cookies (as on recipe). Panelist were required to evaluate the aroma, appearance, taste, mouth feel and overall acceptability of the cookies using a 9point Hedonic scale with $1=$ dislike extremely, $2=$ dislike very much, $3=$ dislike moderately, $4=$ dislike slightly, $5=$ neither like nor dislike, $6=$ like slightly, $7=$ like moderately, $8=$ like very much, 9=like extremely [13].

\subsection{Statistical Analysis}

Statistical package for social science (SPSS) V21 computer software was used to analyze the data. Mean and standard deviation was calculated where appropriate. Analysis of variance (one way ANOVA) was used to determine the treatment that were different from the others in the various parameters tested; differences was considered at 95\% $(p<0.05)$ significant level and $99 \%(p<0.01)$ significant level where mentioned. The Dorcan multiple tests were used to separate means.

\section{Results and Discussion}

\subsection{Functional Properties of Wheat, Almond and Carrot Flour}

The results for the functional properties of flours are shown on Table 3. The values show significant difference in the functional properties. The water absorption capacity of composite cookies ranged from 1.19 to $4.31 \mathrm{~mL} / \mathrm{g}$, foaming capacity of the flours ranged between 5.10 to $6.25 \%$. The bulk density ranged from $0.71 \mathrm{~g} / \mathrm{cm}^{3}$ in carrot and almond flour to $0.81 \mathrm{~g} / \mathrm{cm}^{3}$ in wheat flour, wheat flour recorded the highest 
value for the oil adsorption capacity $7.667 \mathrm{~g} / \mathrm{mL}$ and the lowest in the almond flour $1.100 \mathrm{~g} / \mathrm{mL}$. There was an increase in swelling capacity from 2.3 in wheat flour to $24.5 \%$ in carrot flour. Low water absorption capacity is attributed to compactness of the molecular structure while high value indicates loose structure of the starch polymers [14]. This suggests that the carrot flour has the lesser compact molecular structure and loose starchy structure. Foaming capacity can be influenced by a number of factors which includes temperature, $\mathrm{pH}$, Salt concentration, protein type and method of preparation [15]. These results were consistent to that reported by Ojinnaka et al., [15].

Table 3. Functional properties of wheat, almond and carrot flour.

\begin{tabular}{lllll}
\hline Flour & Bulk density $\left(\mathbf{g} / \mathbf{c m}^{3}\right)$ & W. A. C $(\mathbf{m g} / \mathbf{g})$ & O. A. C $(\mathbf{g} / \mathbf{L})$ & Swelling capacity $(\%)$ \\
\hline wheat & $0.81 \pm 0.01^{\mathrm{a}}$ & $1.199 \pm 0.17^{\mathrm{c}}$ & $3.67 \pm 0.58^{\mathrm{a}}$ & $2.30 \pm 0.26^{\mathrm{c}}$ \\
Almond & $0.71 \pm 0.01^{\mathrm{b}}$ & $1.600 \pm 0.00^{\mathrm{b}}$ & $1.100 \pm 1.00^{\mathrm{c}}$ & $3.73 \pm .23^{\mathrm{b}}$ \\
Carrot & $0.71 \pm 0.01^{\mathrm{b}}$ & $4.311 \pm 0.15^{\mathrm{a}}$ & $2.743 \pm 0.51^{\mathrm{b}}$ & $24.50 \pm 0.50^{\mathrm{a}}$ \\
\hline
\end{tabular}

All data are means of triplicated expressed on dry weight. Different superscripts between columns depict significant difference ( $\mathrm{p} \leq 0.05$ ).

Key: W. A. C=water absorption capacity, O. A. C=oil absorption capacity.

\subsection{Antinutritional Properties of Wheat, Almond and Carrot Flour}

Table 4 reveals the anti-nutrient composition of wheat, and carrot flour. Oxalate content of flours increased significantly from 0.03 in carrot flour to $0.14 \mathrm{mg} / \mathrm{g}$ in almond flour. These values were far less than a value of 0.51 to $1.05 \%$ reported on cookies made from wheat flour and germinated sesame [16]. The phytate detected in the samples were negligible $(0.00 \%)$, a phytate value of 0.03 to $0.18 \%$ was reported on cookies produced from African breadfruit, wheat and pigeon pea flour blends [14]. Phytic acid decreases the availability of some minerals as well as protein, when bound to protein; it induces a decrease of solubility and functionality of the protein. A value of $0.11 \%$ was reported in wheat-cocoyamsoybean cookies [17]. Plant seeds utilize phytate as a source of inorganic phosphate during germination and thus tend to increase palatability, nutritional value and the mineral composition. There was no significant difference in the cyanide content of the flours the mean minimum value where 0.12 for wheat and carrot flour, while almond flour recorded a value of $0.13 \%$. The tannin value increased significantly $(\mathrm{P}<0.05)$ from $0.18 \%$ in wheat flour to $0.64 \%$ in almond flour. There was no significant $(p>0.05)$ difference in the cyanide content in the various flour samples; the highest value of 0.13 was recorded in almond flour while wheat and carrot flour had a cyanide value of $0.12 \%$. Anti-nutrients in food readily reduce the bio availability of nutrients by inhibiting their uptake. A low anti nutrient value as in the results on Table 4 therefore signifies availability of nutrients for assimilation after digestion.

Table 4. Anti-nutritional properties of wheat, almond and carrot flour.

\begin{tabular}{llll}
\hline Flour & Oxalate (mg/100g) & Tannins (\%) & Phytates (\%) \\
\hline Wheat flour & $0.05 \pm 0.01^{\mathrm{b}}$ & $0.18 \pm 0.00^{\mathrm{c}}$ & $0.00 \pm 0.00$ \\
Almond flour & $0.14 \pm 0.00^{\mathrm{c}}$ & $0.64 \pm 0.02^{\mathrm{b}}$ & $0.00 \pm 0.00$ \\
Carrot flour & $0.03 \pm 0.00^{\mathrm{a}}$ & $0.42 \pm 0.00^{\mathrm{a}}$ & $0.00 \pm 0.00$ \\
\hline
\end{tabular}

All data are means of 3 triplicates expressed on dry weighed. Different superscripts between columns depict significant difference ( $\mathrm{p} \leq 0.05$ ).

\subsection{Physical Properties of the Cookies Produced}

In general, incorporation of almond and carrot flour affected diameter, thickness and weight of corresponding cookies. Cookies diameters increased from $3.97 \mathrm{~cm}$ to $4.87 \mathrm{~cm}$; there was significant difference in the thickness with increase in substitution level. Diameter of control sample (100:0:0 wheat cookies) was $3.97 \mathrm{~cm}$ while it increased gradually to $4.87 \mathrm{~cm}$ in sample E (70:20:10). The weight of the control cookie was $8.20 \mathrm{~g}$, the weights increased from $8.20 \mathrm{~g}$ to $11.65 \mathrm{~g}$ in sample $\mathrm{C}$ with $10 \%$ substitution of carrot flour (Table 5). These results showed that the weights of cookies were significantly $(\mathrm{P}<0.05)$ affected by carrot flour substitution than almond flour. The result of the spread ratios ranged from 3.32 in the control sample A to 4.40 in sample E. The lowest value was obtained for $100 \%$ whole wheat cookies while the highest was observed in sample E (70:20:10 substitution). Similar results were reported in cookies produced from whole wheat and full fat soya [18]. The lower the spread ratio the better the crispiness and acceptability of baked products, the lowest spread ratio value was found in sample A (3.32) and the highest value was 4.04 in sample E. The results are similar to that reported by Lutter et al., [19] for cookies produced from wheat/breadfruit. A decrease in the spread ratio of cookies samples was reported on carrot pomace powder incorporated fiber rich cookies by Adepeju et al., [20].

Table 5. Physical properties of cookies.

\begin{tabular}{lllll}
\hline Sample & Weight $(\mathbf{g})$ & $\begin{array}{l}\text { Diameter } \\
(\mathbf{c m})\end{array}$ & $\begin{array}{l}\text { Thickness } \\
(\mathbf{c m})\end{array}$ & $\begin{array}{l}\text { Spread } \\
\text { Ratio }\end{array}$ \\
\hline $\mathrm{A}$ & $8.20 \pm 0.26^{\mathrm{d}}$ & $3.97 \pm 0.15^{\mathrm{c}}$ & $1.20 \pm 0.10^{\mathrm{a}}$ & $3.31 \pm 0.21^{\mathrm{b}}$ \\
$\mathrm{B}$ & $9.17 \pm 0.76^{\mathrm{c}}$ & $4.23 \pm 0.06^{\mathrm{bc}}$ & $1.13 \pm 0.15^{\mathrm{a}}$ & $3.74 \pm 0.50^{\mathrm{ab}}$ \\
$\mathrm{C}$ & $11.67 \pm 0.55^{\mathrm{a}}$ & $4.47 \pm 0.06^{\mathrm{b}}$ & $1.33 \pm 0.06^{\mathrm{a}}$ & $3.36 \pm 0.17^{\mathrm{b}}$ \\
$\mathrm{D}$ & $11.03 \pm 0.15^{\mathrm{ab}}$ & $4.47 \pm 0.06^{\mathrm{b}}$ & $1.30 \pm 0.17^{\mathrm{a}}$ & $3.44 \pm 0.47^{\mathrm{b}}$ \\
$\mathrm{E}$ & $10.60 \pm 0.53^{\mathrm{b}}$ & $4.87 \pm 0.32^{\mathrm{a}}$ & $1.10 \pm 0.10^{\mathrm{a}}$ & $4.43 \pm 0.23^{\mathrm{a}}$ \\
\hline
\end{tabular}

All data are means of 3 triplicates expressed on dry weights. Different superscripts between columns depict significant difference $(\mathrm{p} \leq 0.05)$.

Key: Sample $\mathrm{A}=100 \%$ wheat flour, sample $\mathrm{B}=90 \%$ wheat flour $+10 \%$ almond flour, sample $\mathrm{C}=90 \%$ wheat flour $+10 \%$ carrot flour, sample $\mathrm{D}=80 \%$ wheat flour $+15 \%$ almond flour $+5 \%$ carrot flour, sample $\mathrm{E}=70 \%$ wheat flour $+20 \%$ almond flour $+10 \%$ carrot flour. 


\subsection{Proximate Composition of Cookies Produced}

The results of the proximate composition of cookies showed that; they was a significant difference $(p<0.05)$ in moisture, fat, protein, fiber, carbohydrate content of samples (Table 6), which showed an increase from the control sample. The energy value of cookies increased from $371.22 \mathrm{kCal}$ in the control sample to $391.84 \mathrm{kCal}$ in sample E. The present results are in agreement with the findings of Sanni et al., [14] who reported an increase in moisture content of wheat-cocoyam cookies enriched with soy flour from 7.81 to $9.85 \%$. Baljeet et al., [21] also reported an increase in moisture content of cookies supplemented with carrot pomace powder and germinated chickpea flour. The crude protein content increased from $6.14 \%$ to $10.23 \%$ in sample E due to the addition of almond flour, because of the higher protein content in almond as compared to the wheat. The present results are in complete agreement with the findings of Baljeet et al., [21] who reported an increase in protein content of cookies supplemented carrot pomace powder and germinated chickpea flour. Comparable results were achieved by Baljeet et al., [21] reported a decrease in fiber content of cookies supplemented carrot pomace powder and germinated chickpea flour. While an increase in fiber content of biscuits supplemented with alfalfa seed flour [22]. There was an increase in the ash content of cookies from $1.62 \%$ in sample A to $2.72 \%$ in sample E, suggesting that almond and carrot has higher ash content as compared to wheat. These results were similar to a 1.00 to $1.68 \%$ ash increases on carrot pomace powder incorporated fiber rich cookies [20]. The crude fat content of the cookies increased with the increase of almond flour $(1.94 \%$ in sample A to $6.02 \%$ in sample E, this can be attributed to the high fat content of almond seed as compared to wheat and carrot. These results are in accordance with the findings of Ojinnaka et al., who reported an increase in fat content of biscuits supplemented with alfalfa seed flour [15]. The carbohydrate content decreased in the flour blend due to the addition of almond flour, because of the lower carbohydrate content in the almond and carrot flour as compared to the wheat flour. This result was in line with that report of a decrease in carbohydrate content of carrot pomace powder incorporated fibre rich cookies [23]. Lucretia et al., [24] reported a similar observation. Increase in the moisture, ash, fiber, fat, protein and energy value of the cookies suggest that cookies fortified with almond and carrot flour blends have beneficial nutrients to consumers.

Table 6. Proximate composition of the cookies.

\begin{tabular}{|c|c|c|c|c|c|c|c|}
\hline samples & Moisture (\%) & $\operatorname{Ash}(\%)$ & Fiber $(\%)$ & Fat $(\%)$ & Protein (\%) & Carbohydrate (\%) & Energy value (kCal) \\
\hline A & $6.42 \pm 0.43^{\mathrm{c}}$ & $1.62 \pm 0.14^{b}$ & $0.36 \pm 0.12^{b}$ & $1.94 \pm 0.05^{\mathrm{d}}$ & $6.14 \pm 0.53^{\mathrm{d}}$ & $81.18 \pm 0.13^{\mathrm{a}}$ & $371.22 \pm 0.22^{\mathrm{e}}$ \\
\hline B & $7.43 \pm 0.45^{\mathrm{ab}}$ & $1.68 \pm 0.15^{\mathrm{b}}$ & $0.47 \pm 0.12^{b}$ & $2.51 \pm 0.01^{\mathrm{c}}$ & $7.98 \pm 0.47^{\mathrm{c}}$ & $79.52 \pm 0.40^{\mathrm{c}}$ & $373.51 \pm 0.44^{\mathrm{d}}$ \\
\hline $\mathrm{D}$ & $7.14 \pm 0.22^{b}$ & $2.08 \pm 0.13^{b}$ & $0.58 \pm 0.24^{\mathrm{ab}}$ & $4.01 \pm 0.17^{\mathrm{b}}$ & $8.97 \pm 0.38^{\mathrm{b}}$ & $77.11 \pm 0.14^{\mathrm{d}}$ & $384.81 \pm 0.55^{\mathrm{b}}$ \\
\hline $\mathrm{E}$ & $8.04 \pm 0.09^{\mathrm{a}}$ & $2.72 \pm 0.55^{\mathrm{a}}$ & $0.97 \pm 0.33^{\mathrm{a}}$ & $6.02 \pm 0.27^{\mathrm{a}}$ & $10.23 \pm 0.28^{\mathrm{a}}$ & $71.27 \pm 0.03^{\mathrm{e}}$ & $391.48 \pm 0.54^{\mathrm{a}}$ \\
\hline
\end{tabular}

All data are means of 3 triplicates expressed on dry weight. Different superscripts between columns depict significant difference ( $\mathrm{p} \leq 0.05$ ).

Key: Sample $\mathrm{A}=100 \%$ wheat flour, sample $\mathrm{B}=90 \%$ wheat flour $+10 \%$ almond flour, sample $\mathrm{C}=90 \%$ wheat flour $+10 \%$ carrot flour, sample $\mathrm{D}=80 \%$ wheat flour $+15 \%$ almond flour $+5 \%$ carrot flours, sample $\mathrm{E}=70 \%$ wheat flour $+20 \%$ almond flour $+10 \%$ carrot flour.

\subsection{Mineral Composition in the Cookies Produced}

They were an increase in the mineral: calcium, potassium, and magnesium and sodium composition of cookie samples except for zinc which decreased from 7.12 to $5.75 \mathrm{mg} / 100 \mathrm{~g}$ (Table 7). The increase in calcium and other minerals can be attributed to the high mineral content of almond and carrot. Calcium is necessary for optimal growth and development of infant and young children. Expression of the amount of magnesium per $100 \mathrm{~g}$ of the sample as percentage of the recommended magnesium intake for infants of 7 - 12 months (54 mg day/day) was $>50 \%$ and $>100 \%$ for the $20 \%$ substitution level. A similar result was reported by Lucretia et al., who reported a value of $76.0 \mathrm{mg} / \mathrm{kg}$ in soya beans and carrot flour complementary food [24]. The consumption of 100 $\mathrm{g}$ of the wheat, almond and carrot complementary food would meet the daily requirement. Carrot is also a good source of magnesium, magnesium is involved in over 300 metabolic reactions in the human body and is needed for bone, protein, making new cells, activating $\mathrm{B}$ vitamins, relaxing nerves and muscles, clotting blood, and in energy production etc. [26, 27]. Potassium and magnesium in almond and carrots help in functioning of muscles [26]. The substitution of wheat flour with almond and carrot flour resulted in increase in magnesium content of the cookies. Potassium is an important constituent of every living cell. It is very essential in neuron transmission and other cellular reactions in the body. Zinc is an important co-factor for more than 70 enzymes and plays a central role in cell division, protein synthesis and growth. Zinc deficiency will result to growth failure, anemia, enlarged liver and spleen, impaired skeletal development. Zinc content of the samples decreased with increase in flour substitution. However, the consumption of $100 \mathrm{~g}$ of the wheat, almond and carrot flour formulated cookies will meet $<10 \%$ of the recommended zinc intake for infants of $7-12$ months, $8.6 \mathrm{mg}$ day-1 [25]. Cookies produced by fortifying wheat with almond and carrot flour blends had higher micronutrient content than the control cookie $(100 \%$ wheat flour). Consuming cookies produced from wheat almond and carrot flour blends is the will therefor increase the calcium, potassium, magnesium, and sodium bio availability for body intake. Infants and school going children who are still at the early stage of growth needs this mineral for their growth. 
Table 7. Mineral composition of cookies produced from wheat, almond and carrot flour blends.

\begin{tabular}{llllll}
\hline Sample & $\mathbf{C a}(\mathbf{m g} / \mathbf{1 0 0} \mathbf{g})$ & $\mathbf{K}(\mathbf{m g} / \mathbf{1 0 0} \mathbf{g})$ & $\mathbf{Z n}(\mathbf{m g} / \mathbf{1 0 0} \mathbf{g})$ & $\mathbf{M g}(\mathbf{m g} / \mathbf{1 0 0} \mathbf{g})$ & $\mathbf{N a}(\mathbf{m g} / \mathbf{1 0 0} \mathbf{g})$ \\
\hline A & $185.77 \pm 0.00^{\mathrm{e}}$ & $877.62 \pm 0.01^{\mathrm{e}}$ & $7.12 \pm 0.01^{\mathrm{a}}$ & $58.96 \pm 0.01^{\mathrm{e}}$ & $47.03 \pm 0.09 \mathrm{~d}$ \\
B & $192.17 \pm 0.13^{\mathrm{d}}$ & $941.22 \pm 0.01^{\mathrm{d}}$ & $6.56 \pm 0.01^{\mathrm{b}}$ & $61.25 \pm 0.01^{\mathrm{d}}$ & $48.44 \pm 0.21^{\mathrm{cd}}$ \\
C & $211.43 \pm 0.01^{\mathrm{c}}$ & $958.64 \pm 0.02^{\mathrm{c}}$ & $6.15 \pm 0.01^{\mathrm{c}}$ & $72.16 \pm 0.01^{\mathrm{c}}$ & $50.34 \pm 0.23^{\mathrm{c}}$ \\
D & $225.52 \pm 0.00^{\mathrm{b}}$ & $967.83 \pm 0.01^{\mathrm{b}}$ & $5.79 \pm 0.01^{\mathrm{d}}$ & $75.43 \pm 0.01^{\mathrm{b}}$ & $54.07 \pm 0.11^{\mathrm{b}}$ \\
E & $230.16 \pm 0.01^{\mathrm{a}}$ & $984.26 \pm 0.01^{\mathrm{a}}$ & $5.75 \pm 0.01^{\mathrm{e}}$ & $77.16 \pm 0.01^{\mathrm{a}}$ & $56.12 \pm 0.02^{\mathrm{a}}$ \\
\hline
\end{tabular}

All data are means of 3 triplicates expressed on dry weight. Different superscripts between columns depict significant difference $(\mathrm{p} \leq 0.05)$.

\subsection{Sensory Attributes of Cookies Produced}

Results of the sensory attributes of cookies are presented on Table 8 below. The values showed significant difference for its appearance and general acceptability while they were no significant difference in the texture, taste and aroma of the cookie samples. Sample A had the highest reading for appearance 7.89 and least in sample C 5.94. All cookie samples were generally accepted by the sensory panelist, sample A had the highest value of 7.74 closely followed by sample B 7.37. The statistical results reveal a positive score for all samples in the various parameters. These results showed that cookies produced from wheat, almond and carrot flour blends at substitution levels of 90:10:0, 90:0:10, 80:15:5, 70:20:10 (all samples with blend formulation of: wheat, almond and carrot flour respectively) are generally acceptable by consumers for all its parameters and can be used as a good fortification medium. The results also show that at continuous flour substitution levels with almond and carrot flour, the sensory attributes start declining but the nutritional quality increases. Uptal et al., [28] and Adeye et $a l$. ., [29] reported the same trend of results for the sensory attributes of mushroom enriched biscuits and cookies produced from Sweet Potato- Maize Flour Blends respectively.

Table 8. Sensory attributes of cookies.

\begin{tabular}{llllll}
\hline Sample & Texture & Taste & Aroma & Appearance & General Acceptability \\
\hline A & $7.50 \pm 1.29^{\mathrm{a}}$ & $7.56 \pm 1.20^{\mathrm{a}}$ & $7.11 \pm 1.49^{\mathrm{a}}$ & $7.89 \pm 0.96^{\mathrm{a}}$ & $7.74 \pm 1.10^{\mathrm{a}}$ \\
B & $7.50 \pm 1.50^{\mathrm{a}}$ & $7.44 \pm 1.50^{\mathrm{a}}$ & $6.94 \pm 1.59^{\mathrm{a}}$ & $7.50 \pm 1.10^{\mathrm{ab}}$ & $7.37 \pm 1.34^{\mathrm{a}}$ \\
C & $6.61 \pm 1.69^{\mathrm{a}}$ & $6.72 \pm 1.74^{\mathrm{a}}$ & $6.33 \pm 1.28^{\mathrm{a}}$ & $5.94 \pm 1.73^{\mathrm{d}}$ & $6.95 \pm 1.58^{\mathrm{ab}}$ \\
D & $7.00 \pm 1.53^{\mathrm{a}}$ & $7.33 \pm 1.37^{\mathrm{a}}$ & $6.94 \pm 1.30^{\mathrm{a}}$ & $6.72 \pm 1.27^{\mathrm{bcd}}$ & $7.05 \pm 1.27^{\mathrm{a}}$ \\
E & $7.06 \pm 1.59^{\mathrm{a}}$ & $7.17 \pm 1.58^{\mathrm{a}}$ & $6.67 \pm 1.78^{\mathrm{a}}$ & $6.17 \pm 1.72^{\text {cd }}$ & $7.11 \pm 1.59^{\mathrm{ab}}$ \\
\hline
\end{tabular}

\section{Conclusion}

The present research shows that, supplementation of wheat flour with almond and carrot flour has additional nutritional benefits to consumers. The functional and physical properties of cookies portrayed variable results. Supplementation increased the moisture content, crude fat content, crude fiber content and protein content of cookies produced from wheat, almond and carrot flour blends. The energy value of cookies were also increased significantly $(\mathrm{P}<0.05)$ with increased substitution of wheat flour with almond and carrot flour and their blends. Cookies supplemented with almond, carrot flour and their blends had positive increase in the mineral (calcium, sodium, magnesium, potassium) content except zinc which had a decrease which were within the recommended daily intake values. The sensory attributes of cookies showed that all samples where accepted for their taste, texture, appearance, aroma and general acceptability by the panelist. This shows cookies produced from wheat, almond and carrot flour blends can be produced at respective wheat, almond, and carrot flour ratios of 90:10:0, 90:0:10, 80:15:5, 70:20:10. From the results above cookie substitution of 70:20:10 in sample E was the best sample suitable to fight micronutrient mal-nutrition, having the highest mineral, vitamin, fat, protein, ash, fiber, and energy contents.

\section{Competing Interests}

There is no-conflict of interest in the paper and all the authors are agreed to publish the paper in this journal.

\section{Authors' Contributions}

M. D. G conducted the experiment and collected the data and analysed them; D. A and M. O. E contributed supervision in the experiment, paper formatting, helped to check the English, grammar and also processing process during submission to the journal.

\section{Acknowledgements}

Thanks to the center of food technology and research (CEFTER) Benue state university Nigeria for the study opportunity. Much thanks to Mr. Kame Stephen Mulak and Mrs. Kame Celine for financial assistance.

\section{References}

[1] Lalmuanpuia C, Shankar Suwan Singh and Vipin Kumar Verma. (2017). Preparation and quality assessment of fortified cookies by using wheat flour, flaxseed flour and carrot pomace. The Pharma Innovation Journal; 6 (7): 246-250. 
[2] Akhtar S, Anjum F, Rehman S, Sheikh M and Farzena K, (2008). Effect of fortification on the physico-chemical and microbiological stability of whole wheat flour. Food Chem., 112: $156-163$

[3] Yada. S. Huang, Lapsley. K, and Hung G. W (2011). A review of composition studies of almonds: macronutrients and macronutrients, Journal of food composition analysis, vol. 24. Pp 464-480.

[4] Iwegbue, C. M. A. (2012). Metal contents in some brands of biscuits consumed in southern Nigeria. Amer. J. Food Technol. 7: 160-167.

[5] Jonas T, (2010). Medicinal applications of carrot. Journal of Food and Agric 321, 440-443.

[6] Awogbenja M. D and Ndife J. (2012). Evaluation of infant feeding and care practices among mothers in nassarawaeggon local government area of nassrawa state. Indian Journal of Science Research, 3 (1): 21-29.

[7] Handa. C. S. Goomer and A. Siddhu (2012). "Physicochemical properties and sensory evaluation of fructoligosaccharide enriched cookies". J Food Sci Technol., 49 (2), pp. 192-199.

[8] Okoye, E. C and Onyekwelu, C. N. (2018). Production and quality evaluation of enriched cookies from wheat, african yam bean and carrot composite flours. Annals. Food Science and Technology. 4 (3): 1-8.

[9] Onwuka G. I (2005). Food analysis and instrumentation: Theory and practice. Nigeria: Naphathali Prints.; 95-96.

[10] Olapade A. A, Aworh O. C, Oluwole O. B (2011). Quality attributes of biscuit from acha (Digitaria exilis) flour supplemented with cowpea (Vigna Unguiculata) flour. African Journal of Food Science and Technology.; 2: 198-203.

[11] Krishnaiah D, Devi T, Bono A, Sarbatly R (2009). Studies on phytochemical constituents of six Malaysian medicinal plants. Journal of Medicinal Plant Resources; 3 (2): 67-72.

[12] AOAC (2010). Official methods of analysis. Association of Official Analytical Chemists. 18th edition. Washington D. C. USA.

[13] Akinjayeju O, (2009). Quality control for the industry: A statistical approach. Lagos: Concept Publications. Food Science And Nutrition. 4 (3) 364-369.

[14] Sanni, L. O., Adebowale, A. A. and Tafa, S. O. (2006). Proximate, functional, pasting and sensory qualities of instant yam flour. J. Food Agric. Environ. 4: 74-78

[15] Ojinnaka, M. C. and Nnorom, C. C. (2015). Quality evaluation of wheat-cocoyam-soybean cookies. Nigerian Journal of Agriculture, Food and Environment. 11 (3): 123129.

[16] Olagunju1 A. L and Ifesan B. O. T. (2013). Nutritional Composition and Acceptability of Cookies Made from Wheat
Flour and Germinated Sesame (Sesamum indicum) Flour Blends. British Journal of Applied Science \& Technology 3 (4): 702-713.

[17] U. D. Akpabio (2012). Evaluation of proximate composition, mineral element and anti- nutrient in almond (Terminalia catappa) seeds. Advances in Applied Science Research, 2012, 3 (4): $2247-2252$

[18] Joel N., Fatima K., and Stephen F., (2014). Production and quality assessment of enriched cookies from whole wheat and full fat soya. European Journal of Food Science and Technology. Vol. 2, No. 1, pp. 19-28.

[19] Lutter C. K, Dewey K. G (2003). Proposed Nutrient Composition for Fortified Complementary Foods. J. Nutr., 133: 3011S-3020S.

[20] Adepeju, A. B, Abiodun O. A, Otutu O. L, Pele, I. G (2015). Development and quality evaluation of wheat/breadfruit cookies. International Journal of Technical Research and Applications e-ISSN: 2320-8163.

[21] Baljeet, S. Y., 1Ritika, B. Y. and 2Reena, K. (2014). Effect of incorporation of carrot pomace powder and germinated chickpea flour on the quality characteristics of biscuits. International Food Research Journal. 21 (1): 217-222.

[22] Fahim Ullah 1, Sajjad Ahmad 2, Said Wahab 2, Alam Zeb 2, Mansoor Khan Khattak 3, Saleem Khan 4 and Min Kang (2016). Quality Evaluation of Biscuits Supplemented with Alfalfa Seed Flour. Foods, 5, 68; doi: 10.3390/foods5040068.

[23] Prashant S., and D. M. Shere (2017). Physico-chemical and sensory characteristics of carrot pomace powder incorporated fibre rich cookies. Asian J. Dairy \& Food Res, 36 (4) 2017 : 327-331.

[24] Lucretia I. B, Patience C. O and Enobong M. O, (2017). Proximate composition micronutrient and sensory properties of complementary food formulated from fermented maize, soybeans and carrot flours. Sky Journal of Food Science Vol. 6 (3), pp. 033-039.

[25] WHO/FAO (2004). Vitamin and mineral requirements in human nutrition. Geneva, Switzerland.

[26] Silva Dias JC (2014). Nutritional and Health Benefits of Carrots and Their Seed Extracts. Food and Nutrition Sciences, 5: 2147-2156. http://dx.doi.org/10.4236/fns.2014.522227.

[27] Guerrera M. P, Volpe S. L, Mao J. J (2009). Therapeutic Uses of Magnesium. Am. Fam. Physician. 80: 157-162.

[28] Utpal K. P, Khan M. Murtaja R. L, Md. Fardos A, Jahangir. Md A (2015). Development and quality evaluation of mushroom (pleurotussajor-caju) enriched biscuits. Emirates Journal of Food and Agriculture.. 27 (7): 542-547.

[29] Adeyeye S. A., Akingbala, J. O (2014). Evaluation of Nutritional and Sensory Properties of Cookies Produced from Sweet Potato- Maize Flour Blends. Researcher; 6 (9): 61-70]. (ISSN: 1553-9865). http://www.sciencepub.net/researcher. 